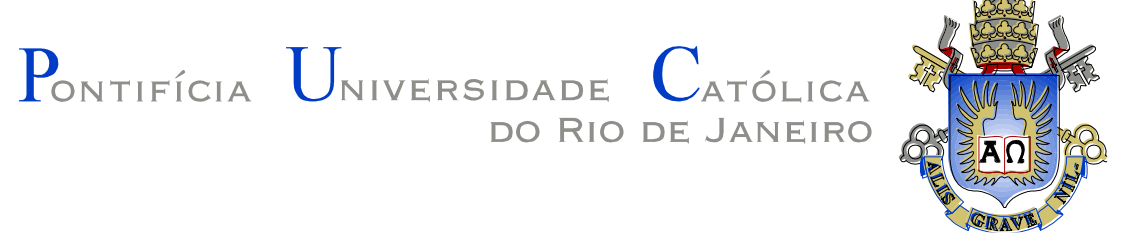

Carolina Figueiredo Cibella de Oliveira Transmissão psíquica de elementos traumáticos na
conjugalidade

Dissertação apresentada como requisito parcial para obtenção do grau de Mestre pelo Programa de Pós-Graduação em Psicologia (Psicologia Clínica) do Departamento de Psicologia do Centro de Teologia e Ciências Humanas da PUC-Rio.

Orientadora: Prof $^{\mathrm{a}}$ Andrea Seixas Magalhães 


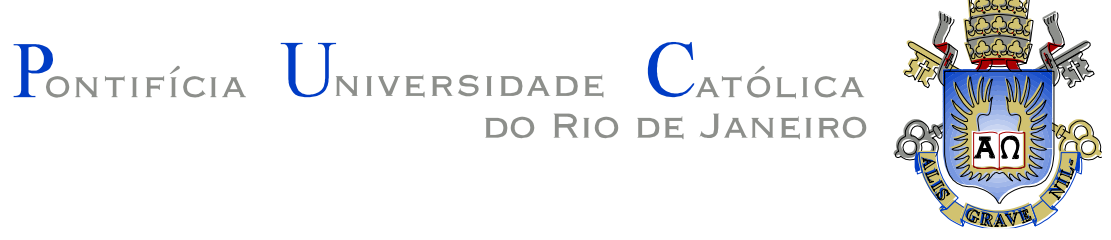

Carolina Figueiredo Cibella de Oliveira

\title{
Transmissão psíquica de elementos traumáticos na conjugalidade
}

\begin{abstract}
Dissertação apresentada como requisito parcial para obtenção do grau de Mestre pelo Programa de Pós-Graduação em Psicologia (Psicologia Clínica) do Departamento de Psicologia do Centro de Teologia e Ciências Humanas da PUC-Rio. Aprovada pela Comissão Examinadora abaixo assinada.
\end{abstract}

\author{
Prof ${ }^{a}$ Andrea Seixas Magalhães \\ Orientadora \\ Departamento de Psicologia - PUC-Rio
}

Prof $f^{a}$ Ana Lila Lejarraga Instituto de Psicologia - UFRJ

Prof ${ }^{\mathrm{a}}$ Terezinha Féres-Carneiro Departamento de Psicologia - PUC-Rio

Profa Denise Berruezo Portinari Coordenadora Setorial de Pós-Graduação e Pesquisa do Centro de Teologia e Ciências Humanas - PUC-Rio

Rio de Janeiro, 11 de fevereiro de 2014. 
Todos os direitos reservados. É proibida a reprodução total ou parcial do trabalho sem a autorização da universidade, da autora e da orientadora.

\section{Carolina Figueiredo Cibella de Oliveira}

Graduou-se em Psicologia no Instituto de Psicologia da Universidade Federal do Rio de Janeiro em 2010. Graduou-se também no curso de bacharelado e licenciatura em Letras (Português-Literaturas) da Universidade do Estado do Rio de Janeiro, em 2007. Atualmente, está em formação psicanalítica na Sociedade Psicanalítica do Rio de Janeiro (SPRJ), filiada à International Psychoanalytical Association. Participa de diversos congressos e jornadas de psicanálise, buscando uma compreensão sobre a clínica e a teoria psicanalíticas.

Ficha Catalográfica

Oliveira, Carolina Figueiredo Cibella de

Transmissão psíquica de elementos traumáticos na conjugalidade / Carolina Figueiredo Cibella de Oliveira ; orientadora: Andrea Seixas Magalhães. - 2014.

119 f. ; $30 \mathrm{~cm}$

Dissertação (mestrado)-Pontifícia Universidade Católica do Rio de Janeiro, Departamento de Psicologia, 2014.

Inclui bibliografia

1. Psicologia - Teses. 2. Conjugalidade. 3. Trauma. 4. Transmissão psíquica. 5. Psicanálise de casal. 6. Identificação. I. Magalhães, Andrea Seixas. II. Pontifícia Universidade Católica do Rio de Janeiro.

CDD: 150 


\section{Agradecimentos}

À minha orientadora, Prof ${ }^{a}$ Andrea Seixas Magalhães, pela cuidadosa leitura e orientação desta pesquisa, assim como pelo carinho com que sempre me tratou nesses dois anos de trabalho conjunto.

Ao meu marido, Henrique, por me apoiar nesse percurso do mestrado, assim como faz de modo geral em minha profissão.

À minha mãe, Maria Lúcia, pelo apoio de sempre e pelo exemplo dado de dedicação ao estudo ao longo de sua vida.

Ao meu pai, Roberto, pelo apoio ao meu trabalho.

Aos meus irmãos, Marcela e Caio, pelo companheirismo e pelas trocas intelectuais que sempre tivemos.

À minha colega de mestrado da PUC-Rio, Janaína, pelas trocas tanto acadêmicas quanto relativas a angústias próprias de mestrandos.

Aos meus colegas da UFRJ, pelas discussões sobre o trauma e, em especial, à Camila, pelos constantes diálogos acadêmicos que enriqueceram em muito esta pesquisa.

Aos professores com os quais tive aula no mestrado da PUC-Rio.

Às professoras que participaram da Comissão Examinadora.

Ao CNPq e à PUC-Rio, pelos auxílios concedidos, que possibilitaram a realização deste trabalho. 


\section{Resumo}

Oliveira, Carolina Figueiredo Cibella de; Magalhães, Andrea Seixas. Transmissão psíquica de elementos traumáticos na conjugalidade. Rio de Janeiro, 2014. 119p. Dissertação de Mestrado - Departamento de Psicologia, Pontifícia Universidade Católica do Rio de Janeiro.

O objetivo desta pesquisa de mestrado é discutir as repercussões da transmissão psíquica inconsciente de elementos traumáticos na constituição da identidade conjugal. O percurso desse trabalho teórico inicia-se com a investigação da dimensão inconsciente da conjugalidade e da escolha amorosa, enfatizando as características específicas do vínculo conjugal. O estudo do conceito de transmissão psíquica inconsciente e dos mecanismos identificatórios que possibilitam a transmissão entre os membros do casal foi necessário para compreender os processos identificatórios na conjugalidade, considerados aspectos relevantes para a formação do eu conjugal. Abordou-se a transmissão psíquica de elementos traumáticos na conjugalidade, enfatizando o aspecto estruturante da transmissão do trauma. Pressupõe-se que os fantasmas que assombram o quarto do casal dizem respeito aos aspectos traumáticos que cada um dos parceiros traz consigo, a partir das experiências com os primeiros objetos de amor - sejam objetos primários ou edípicos - que são reeditados na conjugalidade. Considera-se que essa vivência traumática é constitutiva da conjugalidade normal, ou seja, própria à neurose. Conclui-se que a conjugalidade mobiliza intensa carga pulsional, fruto da transmissão transpsíquica entre os parceiros, mas também fruto do legado que o casal carrega de seus antepassados. A relação do casal abarca, portanto, a reedição de relações objetais do passado, ao mesmo tempo em que o encontro amoroso possibilita o exercício da criatividade e da recriação do eu. A coexistência, muitas vezes difícil, desses dois pólos foi abordada na pesquisa, visando aprofundar a compreensão sobre o paradoxo repetir/criar inerente ao vínculo conjugal.

\section{Palavras-chave}

Conjugalidade; trauma; transmissão psíquica; psicanálise de casal; identificação. 


\section{Abstract}

Oliveira, Carolina Figueiredo Cibella de; Magalhães, Andrea Seixas (Advisor). Psychic transmission of traumatic elements in conjugality. Rio de Janeiro, 2014. 119p. MSc. Dissertation - Departamento de Psicologia, Pontifícia Universidade Católica do Rio de Janeiro.

The aim of this Master thesis is to discuss the impact of unconscious psychic transmission of traumatic elements in the constitution of marital identity. The route of this theoretical work begins with the investigation of the unconscious dimension of conjugality and love choice, emphasizing the specific characteristics of the marital bond. The study of the concept of unconscious psychic transmission and identificatory mechanisms that enable the transmission between members of the couple was required to understand the conjugal identificatory processes considered relevant for the formation of the marital self. The psychic transmission of traumatic elements in conjugality, emphasizing the structural aspect of the transmission of trauma, is adressed. It is assumed that the ghosts that haunt the couple bedroom are related to traumatic aspects that each partner brings from their experiences with the first objects of love - whether primary or oedipal objects -, which are republished in conjugality. It is considered that this traumatic experience is constitutive of the normal conjugality; in other words, related to neurosis. It is concluded that the conjugality mobilizes intense instinctual load, which is not only a result of the transmission between partners, but also the result of the legacy which the couple carries from their ancestors. The couple's relationship, therefore, includes the reissue of object relations of the past, while the tryst allows the exercise of creativity and the re-creation of the ego. The coexistence, which is often difficult, of these two poles was addressed in this research so as to deepen the understanding of the paradox repeat/create inherent in the marital bond.

\section{Keywords}

Conjugality; trauma; psychic transmission; couple psychoanalysis; identification. 


\section{Sumário}

Introdução

1. A dimensão inconsciente da conjugalidade 13

1.1. A conjugalidade no processo de subjetivação 14

1.2. A escolha amorosa em Freud: aspectos narcísicos

e edipianos 17

1.3. A escolha amorosa como uma formação de compromisso 23

1.4. O vínculo conjugal: continuidade ou estrutura inédita? 27

1.5. A transicionalidade nas relações amorosas 31

1.6. Os primórdios na conjugalidade 35

1.7. Os processos identificatórios na conjugalidade 38

1.8. Conjugalidade e transmissão 43

2. A transmissão psíquica inconsciente na conjugalidade $\quad 46$

2.1. Apropriando-se de uma herança: o conceito de transmissão psíquica $\quad 47$

2.2. Transmissão psíquica na obra freudiana:

a neurose como herança 51

2.3. Para além de Freud: a transmissão na constituição psíquica 57

2.4. Processos de identificação entre os membros do casal 63

2.4.1. Introjeção e incorporação na relação de casal 64

2.4.2. Identificação projetiva na dinâmica inconsciente do casal 68

2.5. Aspectos traumáticos da transmissão: para introduzir 71

3. Transmissão psíquica de elementos traumáticos

na conjugalidade

73

3.1. Fantasmas no quarto do casal $\quad 74$

3.2. A questão do trauma em psicanálise 78

3.3. Transmissão transpsíquica na conjugalidade 82

3.4. Reedição de experiências passadas na conjugalidade $\quad 88$

3.5. A fusão simbiótica no casal $\quad 91$

3.6. Manifestações clínicas do traumático na conjugalidade 96

3.7. Para finalizar: um olhar para a clínica de casais 100

4. Considerações finais 104

5. Referências bibliográficas 110 
O amor é isso: duas solidões que se protegem, se tocam e se acolhem. Rainer Maria Rilke 